\title{
Laboratory conditioning modifies properties of gills mitochondria from the Pacific oyster Crassostrea gigas
}

\author{
Dudognon Tony ${ }^{1}$, Guderley Helga ${ }^{4}$, Quere Claudie ${ }^{2}$, Soudant Philippe ${ }^{1}$, Racotta llie ${ }^{3}$, \\ Kraffe Edouard ${ }^{1,3},{ }^{*}$
}

\author{
${ }^{1}$ Univ Europeenne Bretagne, UMR CNRS UBO IRD IFREMER 6539, Inst Univ Europeen Mer, Lab Sci \\ Environm Marin, F-29280 Plouzane, France. \\ ${ }^{2}$ UMR 6539 CNRS UBO IRD IFREMER, IFREMER, Lab Physiol Invertebres, F-29280 Plouzane, \\ France. \\ ${ }^{3}$ Ctr Invest Biol Noroeste CIBNOR, La Paz, Bcs, Mexico. \\ ${ }^{4}$ Univ Laval, Dept Biol, Quebec City, PQ G1K 7P4, Canada.
}

* Corresponding author : Edouard Kraffe, email address : edouard.kraffe@univ-brest.fr

\begin{abstract}
:
Although laboratory experiments allow greater control of environmental conditions than field studies, they have several drawbacks. To analyze physiological responses to forcing environmental variables, experimental conditions should mimic natural conditions as closely as possible. For filter-feeding organisms in particular, diet quality and quantity is one of the environmental parameters that can differ markedly between experimental and field conditions. In the hatchery, Pacific oysters, Crassostrea gigas, commonly show good physiological performance and growth on a mixed algal diet of Tisochrysis lutea, formerly Isochrysis aff. galbana clone Tahiti $(T-I s o)$, and Chaetoceros calcitrans, presumably as it provides a good supply of essential polyunsaturated fatty acids (PUFA) as 20:4n-6, 20:5n-3 and 22:6n3. The present study tests whether the fluctuating biotic and abiotic conditions in the field modify the structure and function of oyster mitochondria. One group of oysters was maintained in the intertidal zone, and the other group was fed the mixed diet in a nearby experimental hatchery under salinity and temperature conditions equivalent to those in the field. After 4 weeks of conditioning, the functional capacities and membrane lipid composition of gill mitochondria were measured. For essential polyunsaturated fatty acids, only the proportion of 20:5n-3 differed between field and laboratory oysters, and confirmed the capacity of the mixed diet $T$-Iso $+C$. gracilis, to provide the essential PUFA. Nevertheless, proportions of other FA (e.g., 22:5n-6 and non-methylene-interrupted FA) differed markedly between laboratory and field-conditioned oysters. Mitochondrial oxygen uptake, cytochrome $\mathrm{C}$ oxidase activity, content of cardiolipin and concentration of cytochrome b were significantly lower in laboratory-conditioned than in field-conditioned oysters. These results indicate that laboratory conditioning, although allowing similar growth and gonad maturation, only partially mimics conditions that allow $C$. gigas to maintain mitochondrial function. Although our experimental design cannot ascertain what difference between experimental laboratory and field conditions led to changes in membrane composition and mitochondrial function, differences in nutritional quality (other than known essential PUFA) and abiotic factors (e.g., oxygen availability, emersion or daily temperature fluctuations) had a major impact on mitochondrial properties in oysters.
\end{abstract}


Although laboratory experiments permit much more control over environmental conditions than field studies, they have drawbacks, including the adequacy and realism of laboratory conditions. Experiments in artificial settings attempt to simplify natural complexity by limiting variation to a small number of factors. However, the constant environmental conditions used in laboratory experiments may be inappropriate for animals that have adapted to fluctuating conditions and may impair physiological and cellular processes (Guerra et al. 2012). Oysters generally inhabit the intertidal zone where they are exposed to large fluctuations in oxygen concentration, temperature, food availability and quality, on hourly, daily and seasonal basis. For marine bivalves, changes in abiotic conditions, such as temperature, oxygenation, salinity and desiccation lead to regulated physiological adjustments that can affect growth and reproduction. At the cellular level, changes in mitochondrial function and membrane composition in response to abiotic factors have been demonstrated in bivalves (Glémet and Ballantyne 1995; Gillis and Ballantyne 1999; Guderley 2004; Sussarellu et al. 2013; Dudognon et al. 2013). This ability to adjust mitochondrial structure and function is thought to be critical in controlling energy production under changing environmental conditions (Guderley 2004; Bremer and Moyes 2011). However, whether fluctuating abiotic and biotic conditions affect mitochondrial structure and function in marine bivalves is unknown.

The use of an appropriate diet in the laboratory is primordial, given the influence of diet on energy acquisition for physiological acclimation and growth. Formulating an adequate diet for filter feeding organisms in hatcheries represents a particular challenge, as filter feeders typically ingest living (mainly phytoplankton) and inert particles suspended in the water column. Cultured phytoplankton is generally used during laboratory conditioning of bivalves (Martínez et al. 2000; Farías and Uriate 2006). Algal shape, size, toxicity, digestibility and biochemical composition affect the nutritional value of microalgal species (Brown et al. 1997). Trial and error has shown that microalgal species used to rear bivalves in hatcheries do not have the same nutritional value and lead to different rates of growth, survival, gametogenesis, embryogenesis, hatching and metamorphosis (Epifanio 1979; Enright et al. 1986; Delaunay et al. 1993; Soudant et al. 1996a, 1996b; Utting and Millican 1997; RicoVilla et al. 2006; Pronker et al. 2008; Marshall et al. 2010).

A major biochemical difference among algae lies in their lipid and, particularly, fatty acid (FA) composition that in turn, affects the composition of the bivalves feeding upon them. 
91 Various studies have established that the polyunsaturated fatty acid (PUFA) composition of 92 bivalve cell membranes changes with microalgal FA composition (Delaunay et al. 1993; Soudant et al. 1999; Pennarun et al. 2003; Delaporte et al. 2003, 2005, 2006; Marshall et al. 2010; Dudognon et al. 2014). Because of their structural role in membranes, modifications of membrane FA composition can modulate membrane protein activities and physiological parameters in mammals (Yamaoka et al. 1988; Senault et al. 1990; Hulbert and Else 1999; Leonard et al. 2001; Hirunpanich et al. 2007), fish (Moya-Falcón et al. 2004; Hamza et al. 2008), and bivalves (Soudant et al. 1996a, 1996b; Delaporte et al. 2003; Delaporte et al. 2006). Given the compositional variety of microalgal FA, a mixture of the microalgae Tisochrysis lutea, formerly Isochrysis aff. galbana clone Tahiti (T-Iso) and Chaetoceros calcitrans or Chaetoceros gracilis is often used as an optimal supply of essential FA that allows adequate performance of oysters under laboratory conditions (Rico-Villa et al. 2006; Dudognon et al., 2014). Nonetheless, comparison of adult oysters fed two algae as monospecific diets (i.e. T-Iso and C. gracilis), shows that although the FA composition of mitochondrial membranes is strongly modified by the FA composition of monoalgal diet, very few functional parameters are modified (Dudognon et al. 2014). Such insensitivity of the oxidative capacities of oyster gill mitochondria to major diet-induced changes of membrane composition suggests that regulated changes and homeostatic mechanisms maintain critical mitochondrial membrane characteristics despite major differences in nutritional quality.

In the present study, we tested how laboratory conditions perform to mimic environmental conditions regarding oyster mitochondrial function. For this purpose, we compared physiological performance and mitochondrial properties of oysters kept under controlled laboratory conditions, with salinity and temperature in the experimental tanks similar to field conditions), and a same lot of oysters reared during the same period in the field where they were exposed to natural fluctuations of biotic and abiotic conditions. Physiological performance was assessed through growth and reproductive investment after 4 weeks of conditioning. Gill mitochondria were isolated from oysters before and after conditioning. We characterized mitochondrial oxidative capacities, cytochrome c oxidase (CCO) and citrate synthase (CS) activity, as well as contents of cytochrome $a, b, c_{1}$ and $c$, and membrane lipid composition. 


\section{Chemicals}

126 All chemicals were purchased from Sigma (Saint Quentin Fallavier, France), unless mentioned otherwise.

\section{Sampling procedures}

130 In May 2010, one hundred Pacific oysters $C$. gigas, shell length ranging from 6 to $8.5 \mathrm{~cm}$ 131 (7.3 \pm 0.2 , mean \pm standard error), originating from the same batch of spat, were obtained from 132 a hatchery in Arcachon, France. After arriving in Brittany, oysters were placed in a mesh bag on a tray in the intertidal zone at Aber Benoitt (North Brittany, $48^{\circ} 32^{\prime} \mathrm{N}, 4^{\circ} 30^{\prime} \mathrm{W}$ ) near the Argenton experimental station. One day after arriving, 50 were placed in a $800 \mathrm{~L}$ flowthrough seawater tank at the Argenton experimental station (IFREMER, Argenton, France), with a water flow of $120{\mathrm{~L} . \mathrm{h}^{-1}}^{-}$In parallel, the other 50 oysters were kept in the mesh bag in the intertidal zone. The experimental tank was supplied with seawater pumped at mid-depth in a tidal dock and partly filtered $(10 \mu \mathrm{m})$ through a bag filter. Thus, salinity and temperature in the experimental tank were similar to field conditions (from $12^{\circ} \mathrm{C}$ on May $20^{\text {th }}$, to $16^{\circ} \mathrm{C}$ on June $\left.22^{\text {nd }}\right)$. The tank was drained and cleaned three times a week.

141 Samples were taken at the start of the experiment (T0, $20^{\text {th }}$ of May 2010) and after 4 weeks of

142 conditioning (Tf, $22^{\text {nd }}$ of June 2010). Total weight was measured on whole animals (flesh + 143 shells) before dissection and mitochondrial preparation. Laboratory oysters were fed $a d$ 144 libitum with a mix of two microalgae: Tisochrysis lutea formerly Isochrysis aff. galbana clone Tahiti (T-Iso) and Chaetoceros gracilis, supplied in equal cell volumes. Cultures were produced in $300 \mathrm{~L}$ cylinders containing $1 \mu \mathrm{m}$ filtered seawater enriched with Conway medium at $24 \pm 1^{\circ} \mathrm{C}$, air- $\mathrm{CO}_{2}(3 \%)$ and mix aerated, under continuous light. Microalgae were harvested at exponential growth phase (6-8 days).

\section{Reproductive activity}

151 Qualitative analysis of gametogenic stage

152 A visceral mass slice (2-3 mm thick) was cut upstream of the adductor muscle, put in a histology cassette and transferred into a modified Davidson's fixative (Latendresse et al. 2002) for 48 h. Fixed tissues were dehydrated in ascending ethanol solutions, cleared with Claral ${ }^{\circledR}$ and embedded in paraffin wax. Five micrometer thick sections were cut, mounted on

156 glass slides, and stained with Harry's hematoxylin-eosin Y. Slides were examined under a

157 light microscope to determine gametogenic stage according to the reproductive scale reported 
by Mann (1979) : stage 0 (inactive), stage 1 (early gametogenesis), stage 2 (late gametogenesis) and stage 3 (ripe).

Quantitative analysis of gonad occupation area

162 Percentage of gonad occupation area was determined on each histological section as described 163 by Enríquez-Díaz et al. (2009). Briefly, slides were scanned with a digital scanner. Gonad 164 area was measured by using image analysis software (Imaq Vision Builder, National 165 Instruments Corp., Austin, Texas, USA).

\section{Mitochondrial analysis}

Mitochondrial analyses were performed on mitochondria isolated from gills. For each group (field and laboratory), six pools containing gills of five individuals were used (each pool contained $2.5 \pm 0.1 \mathrm{~g}$ of gill tissue).

\section{Isolation of mitochondria}

174 Procedures for mitochondrial isolation are detailed in Dudognon et al. (2013). Oxygen consumption was measured immediately on the fresh mitochondrial preparations.

176 A subsample of mitochondrial pellets was stored at $-80^{\circ} \mathrm{C}$ for subsequent assays of enzymatic

177 activities, cytochrome concentrations and lipid extraction.

\section{Measurement of oxygen consumption}

180 Mitochondrial oxygen consumption was measured polarographically using a water-jacketed

$181 \mathrm{O}_{2}$ monitoring system (Qubit System, Kingston, Ontario, Canada). Temperature was controlled at $10^{\circ} \mathrm{C}$ by a circulating refrigerated water bath. For each assay, around $0.8 \mathrm{mg}$ of mitochondrial protein (40 $\mu 1$ mitochondrial preparation) was added to $0.4 \mathrm{ml}$ reaction buffer

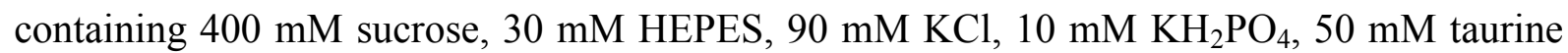
and $50 \mathrm{mM} \beta$-alanine, $\mathrm{pH} 7.5$. On the day of the experiment, $0.5 \% \mathrm{BSA}$ was added to the assay medium. For measurement of maximal oxidative capacities, glutamate $(40 \mathrm{mM})$ or succinate $(20 \mathrm{mM})$ was added to fuel oxygen consumption through complex I or II, respectively. The maximal respiration rate (state 3 ) was obtained after addition of ADP to a final concentration of $600 \mu \mathrm{M}$. Preliminary experiments showed that glutamate alone stimulates respiration through complex I after addition of ADP (Dudognon et al. 2013). Nonphosphorylating oxygen consumption (state 4) rate was measured after ADP depletion. Each measurement was performed in simultaneous triplicates using three polarographic chambers. 
RCR (respiratory control ratio) was defined as the ratio between state 3 and state 4 . Oxidative

194 phosphorylation efficiency (relation between ADP added and oxygen consumption) was calculated as ADP/O ratio according to Estabrook (1967).

\section{Enzymatic activities}

198 Cytochrome $c$ oxidase was measured in mitochondrial preparations and citrate synthase (CS)

199 activity was measured in gill extracts according to Dudognon et al. (2013) and Dudognon et 200 al. (2014), respectively.

\section{Cytochrome concentrations}

203 Cytochromes $a, b, c_{1}$, and $c$ concentrations were quantified by difference spectra according to 204 Leary et al. (2003) except that mitochondrial suspensions (around $0.8 \mathrm{mg}$ of mitochondrial 205 protein) were diluted in phosphate buffer $\left(\mathrm{NaH}_{2} \mathrm{PO}_{4}\right.$ and $\mathrm{Na}_{2} \mathrm{HPO}_{4} 50 \mathrm{mmol} \mathrm{pH} 7.8$ at $\left.25^{\circ} \mathrm{C}\right)$ 206 and Triton-X was not used. Accordingly, the electron transport chain complex was reduced by 207 adding a few grains of sodium dithionite and incubated for $15 \mathrm{~min}$ at room temperature. The reduced samples were read against air-oxidized samples between 400 and $630 \mathrm{~nm}$. We used the solution to the simultaneous equations required to assess individual cytochrome concentrations (Williams Jr. 1964).

\section{Protein concentration}

213 Aliquots of $20 \mu \mathrm{l}$ of mitochondria preparations were suspended in reaction buffer without $214 \mathrm{BSA}$ and centrifuged for $10 \mathrm{~min}$ at $12,000 \mathrm{~g}$ at $4^{\circ} \mathrm{C}$. The supernatant was discarded and the pellet re-suspended, washed and centrifuged twice again to remove the BSA. Pellets were maintained in $0.5 \mathrm{ml}$ of ultra-pure water and frozen at $-80^{\circ} \mathrm{C}$ until protein analysis. The protein concentration was determined with the RC DC Protein Assay Kit (BIORAD) using

218 BSA as standard.

\section{Membrane lipid analysis}

221 The membrane lipids of mitochondrial suspensions were extracted according to the method of Folch et al. (1957). Before lipid extraction, the aliquot of mitochondrial preparation was resuspended in reaction buffer minus BSA and centrifuged at $9000 \mathrm{~g}$ at room temperature for 10 min. The supernatant was discarded and the pellet resuspended, washed in reaction buffer and centrifuged again two times. The final extract was stored at $-80^{\circ} \mathrm{C}$ under nitrogen after adding $0.01 \% \mathrm{w} / \mathrm{v}$ butylated hydroxytoluene (BHT, antioxidant). 
229 Lipid extract was evaporated to dryness under nitrogen, recovered with three washings of $500 \mu 1$ of chloroform/methanol $(98: 2, \mathrm{v} / \mathrm{v})$ and deposited at the top of a silica gel microcolumn (30 mm x $5 \mathrm{~mm}$ i.d.), packed with Kieselgel 60 (70-230 mesh, Merck, Darmstadt, Germany) previously heated at $450^{\circ} \mathrm{C}$ and deactivated with $6 \% \mathrm{H}_{2} \mathrm{O}$ (Marty et al. 1992).

233 Neutral lipids were eluted with $10 \mathrm{ml}$ of chloroform:methanol (98:2, v/v). The polar lipid 234 fraction (membrane lipids) was recovered with $15 \mathrm{ml}$ methanol, and C23:0 solution was added as internal standard for further fatty acid analysis.

\section{Fatty acid analysis of membrane lipids}

238 The polar lipid fraction was evaporated to dryness under nitrogen and transesterified for 10 min at $100^{\circ} \mathrm{C}$ after adding $1 \mathrm{ml}$ of methanol/BF 3 (10\%). After cooling, $1 \mathrm{ml}$ of ultra-pure water and $1 \mathrm{ml}$ of hexane were added. Tubes were mixed thoroughly for $2 \mathrm{~min}$ and centrifuged at $1,000 \mathrm{~g}$ for $10 \mathrm{~min}$. The organic phase containing fatty acid methyl esters (FAME) was washed three times with $1 \mathrm{~mL}$ of water. Fatty acid methyl esters were quantified by gas chromatography and identified by comparing their retention times with those of a standard mixture containing 37 FAME (SUPELCO/Sigma-Aldrich, St-Quentin Fallavier, France), and other lab-made standard mixtures of marine bivalve. A total of 40 FA were quantified and expressed as the molar percentage of the total FA content.

\section{Separation of membrane lipid classes}

249 Phospholipid classes were analyzed by high-performance thin-layer chromatography 250 (HPTLC) as described in details in Dudognon et al. (2014). Mass of each identified phospholipid class was determined by comparison with standards of known amounts. The technique used did not separate phosphatidylinositol

(PI) and ceramideaminoethylphosphonate (CAEP) (unpublished preliminary results), and proportions of these phospholipids were presented as the sum PI + CAEP (CAEP being predominant over PI in oyster gill mitochondria (data not shown)). The sum of PI+CAEP was quantified using sphingomyelin as standard because sphingomyelin has a similar structure to CAEP although is absent in bivalves (Le Grand et al. 2011). Results were expressed as mass\% of total

\section{Statistical analysis} phospholipids. was followed by post hoc Fisher's least significant difference (LSD) test. For data that did not 
follow normality or meet homoscedasticity, non-parametric Kruskal-Wallis analysis was performed. For each test, the significance threshold was $P<0.05$. Percentage data were transformed (arcsin of the square root) before ANOVA but are presented in figures and tables as untransformed percentage values. All analyses were performed with the Statgraphics software, version Plus 5.1. (Manugistics, Inc, Dallas, USA). Results are expressed as mean \pm standard error (SE).

\section{Results}

Oyster weight

Initial oyster weight in trays was $41.7 \pm 2.6 \mathrm{~g}$ (T0) and increased significantly after 4 weeks under both field and laboratory conditions (Figure 1). The two groups of oysters did not differ at the end of conditioning in June (mean values of $56.2 \pm 1.7 \mathrm{~g}$ and $61.0 \pm 2.3 \mathrm{~g}$ for field and laboratory oysters, respectively). No mortality occurred during the experiment.

\section{Gonad maturation stages and gonad coverage area}

Oysters sampled in May were in late gametogenesis (stage 2), whereas those sampled in June were mostly (about $80 \%$ ) reproductively ripe (stage 3 ) (data not shown). Similarly, percentage of gonad coverage area increased significantly $(P<0.01)$ from initial values in May $(43.4 \pm 3.5)$ to final values of $65.1 \pm 3.1 \%$ and $68.8 \pm 2.1 \%$ in oysters from laboratory and field conditions, respectively. There was no difference in gonad occupation area between laboratory and field oysters (Figure 1).

\section{Mitochondrial oxidative capacities}

Oxidative capacities of mitochondria isolated from oyster gills were assessed using glutamate or succinate as substrate. Overall, the capacities of mitochondria isolated from field oysters at Tf were similar to those of oysters at $\mathrm{T} 0$; both were systematically higher than those of laboratory conditioned oysters at Tf (Fig. 2). Maximal state 3 rates of glutamate and succinate oxidation were significantly lower in laboratory oysters than in field oysters for both substrates (around 40\% lower) (Figure 2A). The same pattern was observed with the non-phosphorylating rate (state 4) (Figure $2 \mathrm{~B}$ ). State 4 was significantly higher with succinate than with glutamate (Figure $2 \mathrm{~B}, P<0.05$ ). 
As a consequence of these modifications of state 3 and state 4 rates, RCR with glutamate was

297 lower in laboratory than in field oysters at the end of the experiment (- 25\%) (Table 3). On the other hand, RCR with succinate did not differ at Tf between field and laboratory oysters. $\mathrm{ADP} / \mathrm{O}$ did not differ between field and laboratory oysters for glutamate and succinate, but values were significantly higher for field oysters at T0 compared to Tf for both substrates. $\mathrm{RCR}$ and ADP/O were always significantly higher with glutamate than with succinate as substrate $(P<0.05)$.

Mitochondrial enzyme activities and protein composition

Cytochrome c oxidase and citrate synthase activity

$\mathrm{CCO}$ activity, expressed in $\mathrm{U}_{\mathrm{mg}}{ }^{-1}$ mitochondrial protein, was significantly lower in laboratory conditioned oysters (-33\%), than in field oysters sampled at T0 and Tf (Table 4). As cyt $a$ is located in complex IV (CCO) of the respiratory chain, activity of CCO was also expressed per nmole of cytochrome $a$ to reflect its catalytic activity. In that case, CCO activity did not differ between groups.

311 CS activity, measured on isolated gill tissue and expressed in $\mathrm{U} \mathrm{mg}^{-1}$ gill tissue, did not differ between the three groups of oysters.

\section{Mitochondrial cytochrome concentrations}

315 Cytochrome $b$ concentration did not differ between field oysters at T0 and Tf; both groups 316 had significantly higher values than laboratory conditioned oysters (-24\%) (Table 5). 317 Cytochrome $a, c_{1}$ and $c$ concentrations did not differ between the 3 groups. There was no 318 difference between oyster groups when cytochrome quantities were expressed relative to cytochrome $c_{1}$. Similarly, there was no difference in the ratio $\left(b+c_{1}\right) / a$ between the three groups of oysters.

\section{Fatty acid composition of phospholipids from gill mitochondria}

323 Four weeks under field and laboratory conditions significantly changed the FA composition

324 of membrane phospholipids of oyster gill mitochondria compared to their initial status (T0)

325 (Table 1). More importantly, FA composition differed between rearing conditions at Tf.

326 The proportions of 20:5n-3 decreased throughout the experiment but was higher in 327 mitochondria of field-conditioned oysters than in laboratory-conditioned oysters at Tf. The 328 proportions of 22:6n-3 and 20:4n-6 were also higher at T0, but did not differ between the two 329 groups of oysters at Tf. The proportion of $22: 5 n-6$ was $0.4 \%$ at the start of the experiment and 
330 did not change in oysters after 4 weeks in the field. However, it rose by more than 5 fold $331(2.1 \%)$ in oysters after laboratory conditioning.

332 After 4 weeks conditioning, total NMI (non-methylene interrupted) FA were more abundant 333 in laboratory-conditioned oysters than in field oysters. This difference mainly reflected higher 334 levels of 22:2NMI $(7,15)$ in laboratory-conditioned oysters.

335 The proportion of 18:1n-7 (NMI FA precursor) reached 5.6\% in oysters after 4 weeks in the 336 laboratory while this FA was lower (3.4\%) in oysters from the field at the same time. There 337 was no difference in the proportion of the monounsaturated FA (MUFA) 16:1n-7 between the 338 three groups of oysters. The level of 18:1n-9, 20:1n-9 and 20:1n-7 reached similar levels 339 between laboratory and field oysters after 4 weeks conditioning.

340 The proportion of total saturated FA (SFA), monounsaturated FA (MUFA) and 341 polyunsaturated FA (PUFA) changed markedly throughout the experiment. SFA were higher 342 in mitochondria of oysters from the field than from the laboratory at Tf. At Tf, MUFA were 343 higher in mitochondria of laboratory oysters as compared to field oysters. On the other hand, 344 total PUFA did not differ between the two groups sampled at Tf. Within PUFA, mitochondria 345 of oysters from the laboratory showed the highest proportion of n-6 PUFA but the lowest 346 proportion of n-3 PUFA at the end of the experiment.

\section{Phospholipid classes of mitochondrial membranes}

349 Phosphatidylcholine (PC) and phosphatidylethanolamine (PE) were the main phospholipid 350 classes in mitochondrial membranes of oysters accounting for $64-66.8 \%$ of total 351 phospholipids (Table 2). Phosphatidylinositol (PI) and ceramideaminoethylphosphonate 352 (CAEP) together represented around 20\% and phosphatidylserine (PS) accounted for about $8 \%$ of the total phospholipids. The phospholipid-to-protein ratio (i.e. total phospholipid content expressed per mg of mitochondrial proteins), as well as proportions of PE, PC and PS did not differ among treatments at Tf. The proportions of PI + CAEP increased slightly but significantly after 4 weeks of experimentation and oysters from the laboratory showed a higher proportion of PI + CAEP than oysters from the field. The proportions of CL changed significantly between rearing conditions and laboratory oysters showed lower levels in mitochondria than field oysters at $\mathrm{Tf}$ (by about $-25 \%$ ).

$360 \mathrm{PC} / \mathrm{PE}$ ratio decreased after 4 weeks conditioning and reached significantly lower values in laboratory as compared to field oysters, whereas the ratio PE/CL was higher in mitochondria of oysters from the laboratory than field oysters. 
The similar increase in weight and gonadal occupation between oysters grown in the laboratory and those left in a mesh bag in their natural environment confirmed the suitability of laboratory conditioning for oyster growth and gonad development. Most feeding studies on bivalves use such overall criteria, while few investigate cellular or sub-cellular responses. The present results showed that rearing oysters in laboratory-controlled conditions rather than under fluctuating field conditions decreased the capacities of gill mitochondria, while overall growth and gonad development did not differ.

Major differences of mitochondrial capacities were observed between the groups. Phosphorylating rates of oxygen consumption (state 3) were almost two fold lower in gill mitochondria from laboratory-conditioned oysters. This was true both when isolated mitochondria were fueled with glutamate through complex I or with succinate through complex II. Non-phosphorylating oxygen consumption (state 4) which partly reflects proton leak (St. Pierre et al. 2000) was also consistently lower in laboratory-conditioned oysters.

Differences in mitochondrial oxidative capacities can reflect changes in concentrations or relative levels of electron transport chain complexes (Guderley et al. 2005). Cytochrome $b$ was $24 \%$ less abundant in gill mitochondria from oysters reared in laboratory tanks than in the field. A decrease in cytochrome $b$, a component of complexes II and III of the respiratory chain, may be implicated in the diminished mitochondrial oxidative capacities in laboratory oysters. A concomitant decrease in mitochondrial respiration and in $\mathrm{CCO}$ activity is observed in response to diet in rats (Yamaoka et al. 1988), temperature in fish (Blier and Lemieux 2001); (Kraffe et al. 2007), and hypoxic hibernation in frogs (Boutilier and St-Pierre 2002). $\mathrm{CCO}$ is the last complex of the respiratory chain and can control, at least in part, rates of electron transport through the electron transport chain (Groen et al. 1982). Therefore, diminished CCO activity could be one cause of reduced mitochondrial oxidative capacity in gills of laboratory conditioned oysters.

Phospholipid classes and their FA composition influence the activity of membranebound proteins, such as respiratory chain complexes in mitochondria (Robinson 1993; Stuart et al. 1998; Frick et al. 2010). Phospholipid proportions in mitochondrial membranes differed between laboratory and field oysters. Among these differences, the lower levels of CL in gill mitochondria of laboratory oysters could explain the lower activity of CCO. Indeed, CL is specifically located in the inner membrane of mitochondria and its association with respiratory chain enzymes is of major importance for regulation of their activity and the generation of the inner membrane potential (Schlame et al. 2000; Haines and Dencher 2002; 
Sedlák et al. 2006; Zhou et al. 2011; Böttinger et al. 2012; Kagan and Epand, 2014). A reduced level of CL is associated with decreased mitochondrial activity in mammals (Paradies et al. 1997), snails (Stuart et al. 1998) and fishes (Frick et al. 2010). CL deficiency also induces destabilization, decreased activity and loss of complex III (Schlame et al. 2000; Lange et al. 2001; Petrosillo et al. 2003; Böttinger et al. 2012), potentially explaining the lower cytochrome $b$ content in laboratory conditioned oysters

The FA composition of phospholipids influence the activity of membrane-bound proteins, either through overall or micro-environment localized effects (Robinson 1993; Phillips et al. 2009; Hulbert and Else 1999). Proportions of SFA were higher and those of MUFA lower in gill mitochondria from field oysters than laboratory conditioned oysters. These overall differences may well have changed mitochondrial oxygen uptake and CCO activity. The results of a partner study indicate that maintenance of overall aspects of membrane FA composition (total SFA, MUFA and PUFA) despite marked changes in the levels of individual FA may be key for the maintenance of mitochondrial function in oyster gills (Dudognon et al., 2014) as reported in mammals (Astorg and Chevalier 1991; Lemieux et al. 2008; Abbott et al. 2012) and fish (Guderley et al. 2008; Martin et al. 2013).

In the experimental tank, feeding oysters ad libitum with a mixture of the two microalgae T.Isochrysis lutea, and Chaetoceros gracilis permited a balanced supply of essential FA as 20:4n-6, 20:5n-3 and 22:6n-3 for oysters (Delaunay et al., 1993; Soudant et al. 1996a; Delaporte et al., 2005; Rico-Villa et al. 2006; Marshall et al., 2010; Dudognon et al. 2014). Laboratory and field conditioned oysters had indeed similar levels of the essential FA in gill mitochondria, with the exception of 20:5n-3, confirming that the mixed diet T-Iso $+C$. gracilis provided sufficient essential FA. Nevertheless, differences of some particular FA (i.e. 22:5n-6 and NMI FA) between laboratory and field oysters may be important for the regulation of mitochondrial membrane protein activities (Zhou et al. 2011; Khairallah et al. 2012). Whereas 22:5n-6 appears to be preferentially incorporated from the microalgae T. Iso (Soudant et al, 1996a; Soudant et al. 1996c; Dudognon et al. 2014), NMI FA are the only long chain PUFA that bivalves synthesize de novo (Zhukova 1991). Both 22:5n-6 and NMI FA have been identified as potentially significant for the physiology of bivalve larvae and the structure and fluidity of membranes in female gametes (Soudant et al. 1996a; Soudant et al., 1996c; Pernet et al. 2005; Mike et al. 2008), for membrane functions of bivalve hemocytes (Le Grand 2011, 2013; Dudognon et al. 2014) as well as for peroxidation resistance and activities of gills and gill mitochondria of bivalves (Dudognon et al. 2014; Munro and Blier 2012; Barnathan 2009; Delaporte et al. 2005; Kraffe et al. 2004). 
Changes in several characteristics, ranging from cytochrome contents to phospholipid proportions and FA characteristics, could explain the loss of capacity of gill mitochondria from oysters conditioned in the laboratory. A loss of capacity after laboratory conditioning also occurred in mitochondria from various tissues of the scallop, Argopecten purpuratus (Guderley et al. 2011). One hypothesis questions whether the bi-specific algal diet contains what oysters need to maintain mitochondrial activity. Beside their content in FA, carbohydrate or amino acids, microalgal species also vary significantly in contents of vitamins, minerals and trace elements (Brown 2002). In mammals, these compounds are critical cofactors that support mitochondrial functions. Deficiencies in some minerals and vitamins can reduce activities of electron transport complexes and cardiolipin content in mammals (Ames et al. 2005; Oliveros et al. 2007). As growth rates and gametogenesis did not differ between laboratory and field oysters, the bispecific algal diet should have provided enough energy for somatic growth and gametes maturation, but may have been lacking materials for mitochondrial activity. Finally, the continuous ad libitum feeding we used in the laboratory can be unfavourable for intertidal bivalves such as oysters (Utting et Spencer 1991; Racotta et al. 1998; Hurtado et al. 2009), and may have decreased mitochondrial performance.

Nutrient supply may not be the only environmental factor that could have impacted mitochondrial functions and compositions in oysters. Laboratory conditioned oysters were constantly immersed in well-aerated filtered seawater whereas field oysters had to cope with marked variations in physical, chemical and biological parameters (e.g. temperature, oxygenation and feeding activity during emersion and immersion cycles), linked to tidal cycles. Modifications of environmental conditions, including salinity, hypoxia and temperature, change the structure and function of bivalve mitochondria (Glémet and Ballantyne 1995; Gillis and Ballantyne 1999; Guderley 2004; Sussarellu et al. 2013; Dudognon et al. 2013). Our observations suggest that variable environmental conditions in the field may have stressed changes in specific lipid constituents of mitochondrial membranes and modified mitochondrial capacities.

\section{Conclusion}

Standardized conditions and ad libitum feeding of oysters with a mixed plankton diet do not fully mimic field conditions. Changes of specific FA and phospholipid classes in mitochondrial membranes may explain the lower mitochondrial capacities in laboratoryconditioned oysters. Field conditions impose fluctuations and differences in abiotic and biotic 
470 factors that may have led structural and functional properties of gill mitochondria to differ 471 from those of laboratory conditioned oysters. Nonetheless, overall "fitness" was not affected 472 as oysters showed similar growth and gonadal development in the field and laboratory. 473 Nevertheless, the changed mitochondrial capacities suggest that cellular processes in oysters 474 held in constant laboratory conditions are reduced compared to those of oysters living in the 475 intertidal zone. This could impair other physiological and cellular processes. It may be for 476 example questionable why oysters fed ad libitum and probably having access to more food 477 and for a longer period of time did not grow better in the laboratory.

478

479

480

481

482

483

484 We are grateful to all co-workers from the Argenton experimental station for taking care of 485 486 487 oysters during the experimental conditioning. Many thanks to Marc Long for helping in tissue grinding and lipid analysis, to Caroline Fabioux and Jean-Philippe Beguel for helping in dissections, to Rossana Sussarellu for helping in mitochondrial preparations. Tony Dudognon's fellowship was provided by the French Research Ministry. Funding for the experiment was provided by the project in Europole Mer (research consortium on marine science and technology in Brittany, France): LIPIDOMITO. The corresponding author also 492 493 
Abbott SK, Else PL, Atkins TA, Hulbert AJ (2012) Fatty acid composition of membrane bilayers: Importance of diet polyunsaturated fat balance. BBA-Biomembranes 1818:13091317

Ames BN, Atamna H, Killilea DW (2005) Mineral and vitamin deficiencies can accelerate the mitochondrial decay of aging. Mol Aspects of Med 26:363-378

Astorg PO, Chevalier J (1991) Phospholipid fatty acid composition and respiratory properties of heart and liver mitochondria from rats fed with or deprived of linolenic acid. Nutr Res $11: 71-77$

Barnathan G (2009). Non-methylene-interrupted fatty acids from marine invertebrates:occurrence, characterization and biological properties. Biochimie 91, 671-678.

Blier PU, Lemieux H (2001) The impact of the thermal sensitivity of cytochrome c oxidase on the respiration rate of Arctic charr red muscle mitochondria. J Comp Physiol B 171:247-253

Böttinger L, Horvath SE, Kleinschroth T, Hunte C, Daum G, Pfanner N, Becker T (2012) Phosphatidylethanolamine and cardiolipin differentially affect the stability of mitochondrial respiratory chain supercomplexes. J Mol Biol 423:677-686

Boutilier RG, St-Pierre J (2002) Adaptive plasticity of skeletal muscle energetics in hibernating frogs: mitochondrial proton leak during metabolic depression. J Exp Biol 205:2287-2296

514 Bremer K, Moyes CD (2011) Origins of variation in muscle cytochrome c oxidase activity within and between fish species. J Exp Biol 214:1888-1895

516 Brown MR, Jeffrey SW, Volkman JK, Dunstan G. (1997) Nutritional properties of microalgae 517 for mariculture. Aquaculture 151:315-331

518 Brown MR (2002) Nutritional value of microalgae for aquculture. In: Cruz-Suárez L E, 519 Ricque-Marie D, Tapia-Salazar M, Gaxiola-Cortés M G, Simoes N (ed) Avances En 520 Nutrición Acuícola VI. Memorias Del VI Simposium Internacional De Nutrición Acuícola, 521 Cancún, Quintana Roo, México,

522 Delaporte M, Soudant P, Moal J, Lambert C, Quéré C, Miner P, Choquet G, Paillard C, 523 Samain JF (2003) Effect of a mono-specific algal diet on immune functions in two bivalve 524 species - Crassostrea gigas and Ruditapes philippinarum. J Exp Biol 206:3053-3064

525 Delaporte M, Soudant P, Moal J, Kraffe E, Marty Y, Samain JF (2005) Incorporation and 526 modification of dietary fatty acids in gill polar lipids by two bivalve species Crassostrea gigas and Ruditapes philippinarum. Comp Biochem Phys A 140:460-470

528 Delaporte M, Soudant P, Moal J, Giudicelli E, Lambert C, Séguineau C, Samain JF (2006) 529 Impact of 20:4n-6 supplementation on the fatty acid composition and hemocyte parameters of 530 the Pacific oyster Crassostrea gigas. Lipids 41:567-576 
Delaunay F, Marty Y, Moal J, Samain JF (1993) The effect of monospecific algal diets on 173:163-179

534 Dudognon T, Soudant P, Seguineau C, Quere C, Auffret M, Kraffe E (2013) Functional capacities of gill mitochondria in oyster Crassostrea gigas during an emersion/immersion tidal cycle. Aquat Living Resour 26:249-256

Dudognon T, Soudant P, Lambert C, Quere C, Auffret M, Kraffe E (2014) Mitochondrial activity, hemocyte parameters and lipid composition modulation by dietary conditioning in the Pacific oyster Crassostrea gigas. J. Comp. Physiol. B, 184, 303-317

540 Enright CT, Newkirk GF, Craigie JS, Castell JD (1986) Growth of juvenile Ostrea edulis L. fed Chaetoceros gracilis Schutt of varied biochemical composition. J Exp Mar Biol Ecol 96: $15-26$

Enríquez-Díaz M, Pouvreau S, Chávez-Villalba J, Le Pennec M (2009) Gametogenesis, reproductive investment, and spawning behavior of the Pacific giant oyster Crassostrea gigas: evidence of an environment-dependent strategy. Aquacult Int 17:491-506

Epifanio CE (1979) Growth in bivalve molluscs: Nutritional effects of two or more species of algae in diets fed to the American oyster Crassostrea virginica (Gmelin) and the hard clam Mercenaria mercenaria (L.). Aquaculture 18:1-12

Estabrook RW (1967) Mitochondrial respiratory control and the polarographic measurement of ADP: O ratios. In: Estabrook RW and Pullman ME (ed) Oxidation and Phosphorylation, Academic Press. New York, pp 41-47

Farias A, Uriarte I (2006) Nutrition in pectinids. In: S. E. Shumway \& G. J. Parsons, editors. Scallops: biology, ecology and aquaculture. Amsterdam: Elsevier, pp. 521-542.

Folch J, Lees M, Sloane-Stanley G H (1957). A simple method for the isolation and purification of total lipides from animal tissues. J Biol Chem 226, 497-509

Frick NT, Bystriansky JS, Ip YK, Chew SF, Ballantyne JS (2010) Cytochrome c oxidase is regulated by modulations in protein expression and mitochondrial membrane phospholipid composition in estivating African lungfish. Am J Physiol Reg Integr Comp Physiol 298:608616

Gillis TE, Ballantyne JS (1999) Influences of subzero thermal acclimation on mitochondrial membrane composition of temperate zone marine bivalve mollusks. Lipids 34:59-66

Glémet HC, Ballantyne JS (1995) Influences of environmental salinity on the structure and function of gill mitochondrial membranes of an osmoconforming invertebrate, Crassostrea virginica. Mar Biol 121:673-683 the contribution of various steps to the control of mitochondrial respiration. J Biol Chem 257:2754-2757 
Guderley H, Turner N, Else PL, Hulbert AJ (2005) Why are some mitochondria more powerful than others: insights from comparisons of muscle mitochondria from three terrestrial vertebrates. Comp Biochem Phys B 142:172-180

Guderley H, Kraffe E, Bureau W, Bureau DP (2008) Dietary fatty acid composition changes mitochondrial phospholipids and oxidative capacities in rainbow trout red muscle. $\mathrm{J}$ Comp Physiol B 178:385-399

Guderley H, Brokordt K, Pérez Cortes HM Marty Y and Kraffe E (2011) Diet and performance in the scallop, Argopecten purpuratus: force production during escape responses and mitochondrial oxidative capacities. Aquatic Living Resources 24: 261-271.

Guerra C, Maeda-Martínez AN, Hernandez-Llamas A, Sicard-González MT, Koenigstein S, Abele D, Philipp EER (2012) The influence of temperature and presence of predators on growth, survival and energy allocation for reproduction in the Catarina scallop Argopecten ventricosus. Aquac Res 43:756-766

Haines TH, Dencher NA (2002) Cardiolipin: a proton trap for oxidative phosphorylation. FEBS Lett 528:35-39

Hamza N, Mhetli M, Khemis IB, Cahu C, Kestemont P (2008) Effect of dietary phospholipid levels on performance, enzyme activities and fatty acid composition of pikeperch (Sander lucioperca) larvae. Aquaculture 275:274-282

Hazel JR, Williams EE (1990) The role of alterations in membrane lipid composition in enabling physiological adaptation of organisms to their physical environment. Prog Lipid Res 29:167-227

593 Hirunpanich V, Sethabouppha B, Sato H (2007) Inhibitory effects of saturated and 594 polyunsaturated fatty acids on the cytochrome P450 3A activity in rat liver microsomes. Biol 595 Pharm Bull 30:1586-1588

596 Hulbert AJ, Else PL (1999) Membranes as possible pacemakers of metabolism. J Theor Biol $597 \quad 199: 257-274$

598 Hurtado MA, Ramírez JL, Rodríguez-Jaramillo C, Tovar D, Ibarra AM, Soudant P, Palacios 599 E (2009) Comparison of continuous and batch feeding systems on maturation, biochemical 600 composition and immune variables of the oyster Crassostrea corteziensis (Hertlein 1951). 601 Aquacul Res, 40:464-472

602 Kagan VE, Epand, RM (2014) Deciphering the mysteries of cardiolipins in mtochondria. 603 Chem Phys Lipids, 179:1-2

604 Khairallah RJ, Kim J, O’Shea KM, O’Connell KA, Brown BH, Galvao T, Daneault C, 605 Rosiers CD, Polster BM, Hoppel CL, Stanley, WC (2012) Improved mitochondrial function 606 with diet-induced increase in either docosahexaenoic acid or arachidonic acid in membrane 607 phospholipids. PLoS ONE 7(3):e34402. doi:10.1371/journal.pone.0034402

608 Kraffe E, Marty Y, Guderley H (2007) Changes in mitochondrial oxidative capacities during 609 thermal acclimation of rainbow trout Oncorhynchus mykiss: roles of membrane proteins, 610 phospholipids and their fatty acid compositions. J Exp Biol 210:149-165 
611 Kraffe, E., Soudant, P., Marty, Y. (2004) Fatty acid composition of serine, ethanolamine and 612 choline plasmalogens in some marine bivalves. Lipids, 39:1, 59-66

613 Lange C, Nett JH, Trumpower BL, Hunte C (2001) Specific roles of protein-phospholipid 614 interactions in the yeast cytochrome $b c 1$ complex structure. EMBO J 20:6591-6600

615 Latendresse JR, Warbrittion AR, Jonassen H, Creasy DM (2002) Fixation of testes and eyes 616 using a modified Davidson's fluid: comparison with Bouin's fluid and conventional 617 Davidson's fluid. Toxicol Pathol 30:524-533

618 Leary SC, Lyons CN, Rosenberger AG, Ballantyne JS, Stillman J, Moyes CD (2003) Fiber619 type differences in muscle mitochondrial profiles. Am J Physiol Reg Integr Comp Physiol $620 \quad 285: 817-826$

621 Le Grand F, Kraffe E, Marty Y, Donaghy L, Soudant P (2011) Membrane phospholipid composition of hemocytes in the Pacific oyster Crassostrea gigas and the Manila clam Ruditapes philippinarum. Comp Biochem Phys A 159:383-391

Le Grand F, Soudant P, Marty Y, Le Goïc N, Kraffe E (2013) Altered membrane lipid composition and functional parameters of circulating cells in cockles (Cerastoderma edule) affected by disseminated neoplasia. Chem Phys Lipids 167-168:9-20

Lemieux H, Blier PU, Tardif JC (2008) Does membrane fatty acid composition modulate mitochondrial functions and their thermal sensitivities? Comp Biochem Phys A 149:20-29

Leonard F, Haag M, Kruger MC (2001) Modulation of intestinal vitamin D receptor availability and calcium ATPase activity by essential fatty acids. Prostag Leukotr Ess 64:147$631 \quad 150$

Mann R (1979) Some biochemical and physiological aspects of growth and gametogenesis in Crassostrea gigas and Ostrea edulis grown at sustained elevated temperatures. J Mar Biol Assoc UK 59:95-110

Martin N, Bureau DP, Marty Y, Kraffe E, Guderley H (2013) Dietary lipid quality and mitochondrial membrane composition in trout: responses of membrane enzymes and oxidative capacities. J Comp Physiol B 183:393-408

Martínez G, Aguilera C, Mettifogo L (2000) Interactive effects of diet and temperature on reproductive conditioning of Argopecten purpuratus broodstock. Aquaculture 183:149-159

640 Marty Y, Delaunay F, Moal J, Samain JF (1992) Changes in the fatty acid composition of 641 Pecten maximus (L.) during larval development. J Exp Mar Biol Ecol 163:221-234

642 Marshall R, McKinley S, Pearce CM (2010) Effects of nutrition on larval growth and survival 643 in bivalves. Reviews in Aquaculture 2:33-55

644 Mike LM, Bricelj VM, Parrish CC (2008) Biochemical characterization and nutritional value 645 of three Pavlova spp. in unialgal and mixed diets with Chaetoceros muelleri for postlarval sea 646 scallops, Placopecten magellanicus. Aquaculture 276:130-142

647 Moya-Falcón C, Hvattum E, Dyrøy E, Skorve J, Stefansson SO, Thomassen MS, Jakobsen 648 JV, Berge RK, Ruyter B (2004) Effects of 3-thia fatty acids on feed intake, growth, tissue 649 fatty acid composition, beta-oxidation and $\mathrm{Na}^{+}, \mathrm{K}^{+}$-ATPase activity in Atlantic salmon. Comp 650 Biochem Phys B 139:657-668 
Munro D, Blier PU (2012) The extreme longevity of Arctica islandica is associated with increased peroxidation resistance in mitochondrial membranes. Aging Cell 11:845-855

653 Oliveros LB, Domeniconi MA, Vega VA, Gatica LV, Brigada AM, Gimenez MS (2007) 654 Vitamin A deficiency modifies lipid metabolism in rat liver. Brit J Nutr 97:263-272

655 Paradies G, Ruggiero FM, Petrosillo G, Quagliariello E (1997) Age-dependent decline in the 656 cytochrome $c$ oxidase activity in rat heart mitochondria: role of cardiolipin. FEBS Lett 657 406:136-138

658 Pennarun A-L, Prost C, Haure J, Demaimay M (2003) Comparison of two microalgal diets. 1. 659 Influence on the biochemical and fatty acid compositions of raw oysters (Crassostrea gigas). 660 J Agr Food Chem 51:2006-2010

661 Pernet F, Bricelj VM, Parrish CC (2005) Effect of varying dietary levels of $\omega 6$ 662 polyunsaturated fatty acids during early ontogeny of the sea scallop Placopecten 663 magellanicus. J Exp Mar Biol Ecol 327: 115-133

664 Petrosillo G, Ruggiero FM, Di Venosa N, Paradies G (2003) Decreased complex III activity 665 in mitochondria isolated from rat heart subjected to ischemia and reperfusion: role of reactive 666 oxygen species and cardiolipin. FASEB J 17:714-716

Phillips R, Ursell T, Wiggins P, Sens P (2009) Emerging roles for lipids in shaping membrane-protein function. Nature 459:379-385

Pronker AE, Nevejan NM, Peene F, Geijsen P, Sorgeloos P (2008) Hatchery broodstock conditioning of the blue mussel Mytilus edulis (Linnaeus 1758). Part I. Impact of different micro-algae mixtures on broodstock performance. Aquacult Int 16:297-307

Racotta IS, Ramírez JL, Avila S, Ibarra AM (1998) Biochemical composition of gonad and muscle in the catarina scallop, Argopecten ventricosus, after reproductive conditioning under two feeding systems. Aquaculture 163: 111-122

Rico-Villa B, Le Coz JR, Mingant C, Robert R (2006) Influence of phytoplankton diet mixtures on microalgae consumption, larval development and settlement of the Pacific oyster Crassostrea gigas (Thunberg). Aquaculture 256:377-388

Robinson NC (1993) Functional binding of cardiolipin to cytochrome c oxidase. J Bioenerg 679 Biomembr 25:153-163

680 Schlame M, Rua D, Greenberg ML (2000) The biosynthesis and functional role of cardiolipin. 681 Prog Lipid Res 39:257-288

682 Sedlák E, Panda M, Dale MP, Weintraub ST, Robinson NC (2006) Photolabeling of 683 cardiolipin binding subunits within bovine heart cytochrome c oxidase. Biochemistry 45:746684754

685 Senault C, Yazbeck J, Goubern M, Portet R, Vincent M, Gallay J (1990) Relation between 686 membrane phospholipid composition, fluidity and function in mitochondria of rat brown 687 adipose tissue. Effect of thermal adaptation and essential fatty acid deficiency. Biochim 688 Biophys Acta 1023:283-289 
692 Soudant P, Marty Y, Moal J, Samain J (1996b) Fatty acids and egg quality in great scallop. 693 Aquacult Int 4:191-200

694 Soudant P, Moal J, Marty Y, Samain JF (1996c) Impact of the quality of dietary fatty acids on metabolism and the composition of polar lipid classes in female gonads of Pecten maximus (L.). J Exp Mar Biol Ecol 205:149-163

Soudant P, Van Ryckeghem K, Marty Y, Moal J, Samain JF, Sorgeloos P (1999) Comparison of the lipid class and fatty acid composition between a reproductive cycle in nature and a standard hatchery conditioning of the Pacific Oyster Crassostrea gigas. Comp Biochem Phys B 123:209-222

701

702

703

704

705

706

707

708

709

710

711

712

713

714

715

716

717

718

719

720

721

722

723

724

725

726
St-Pierre J, Brand MD, Boutilier RG (2000) The effect of metabolic depression on proton leak rate in mitochondria from hibernating frogs. J Exp Biol 203:1469-1476

Stuart JA, Gillis TE, Ballantyne JS (1998) Compositional correlates of metabolic depression in the mitochondrial membranes of estivating snails. ails. Am J Physiol Regul Integr Comp Physiol 275:1977-1982

Sussarellu R, Dudognon T, Fabioux C, Soudant P, Moraga D, Kraffe, E (2013) Rapid mitochondrial adjustments in response to short-term hypoxia and re-oxygenation in the Pacific oyster Crassostrea gigas. J. Exp. Biology 216: 1561-1569

Utting SD, Spencer BE (1991) The Hatchery Culture of Bivalve Mollusc Larvae and Juveniles. Laboratory Leaflet, Ministry of Agriculture, Fisheries and Food, Directorate of Fisheries Research, Lowestoft (68), 31 pp.

Utting SD, Millican PF (1997) Techniques for the hatchery conditioning of bivalve broodstocks and the subsequent effect on egg quality and larval viability. Aquaculture $155: 45-54$

Williams Jr. JN (1964) A method for the simultaneous quantitative estimation of cytochromes $\mathrm{a}, \mathrm{b}, \mathrm{c}_{1}$, and $\mathrm{c}$ in mitochondria. Arch Biochem Biophys 107:537-543

Yamaoka S, Urade R, Kito M (1988) Mitochondrial function in rats is affected by modification of membrane phospholipids with dietary sardine oil. J Nutr 118:290-296

Zhou M, Morgner N, Barrera NP, Politis A, Isaacson SC, Matak-Vinković D, Murata T, Bernal RA, Stock D, Robinson CV (2011) Mass spectrometry of intact V-type ATPases reveals bound lipids and the effects of nucleotide binding. Science 334:380-385

Zhukova NV (1991) The Pathway of the Biosynthesis of Non-Methylene-Interrupted Dienoic Fatty Acids in Molluscs, Comp.Biochem. Phys. 100B, 801-804 

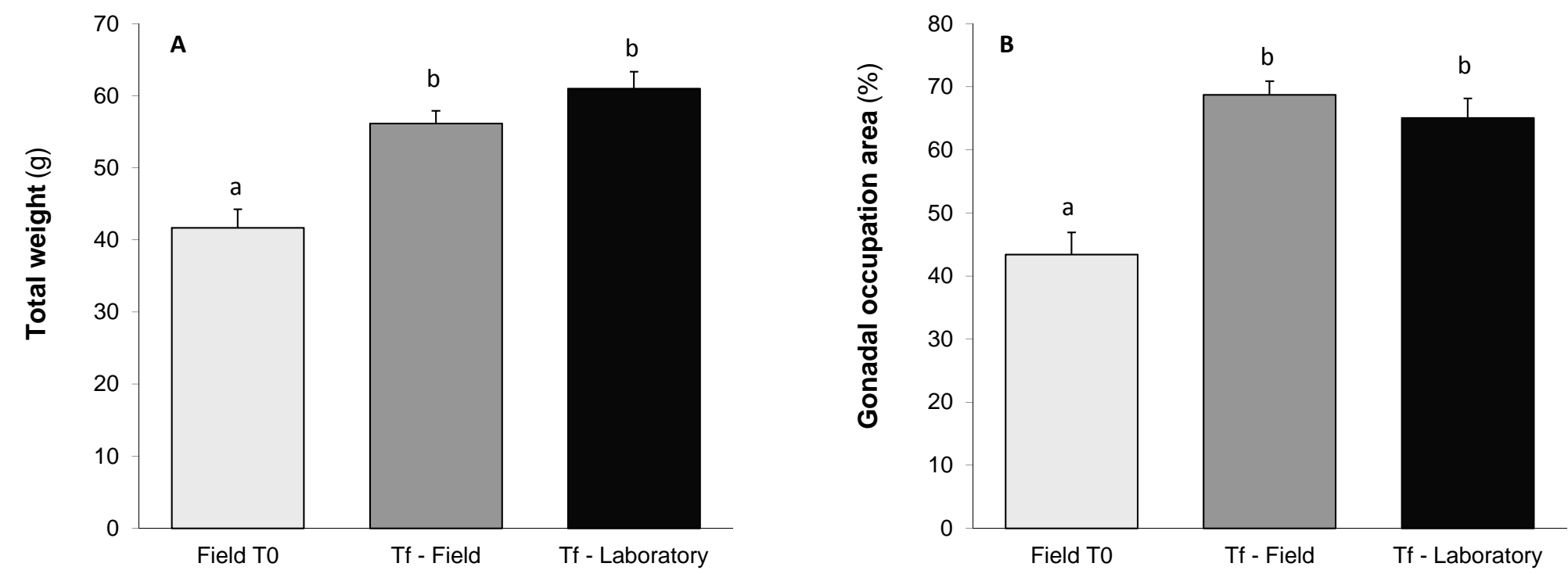

Figure 1: Total weight (expressed as g) (A) and gonad occupation area (expressed as \%) (B) of oysters ( $\mathrm{n}=30)$ grown on their natural environment or in the laboratory, and sampled before (Field $\mathrm{T} 0$ ) and after 4 weeks of conditioning ( $\mathrm{Tf}$ - Field, Tf - Laboratory). Values are mean \pm SE. Different superscript letters indicate values that differ significantly (p<0.05) between oyster groups. 

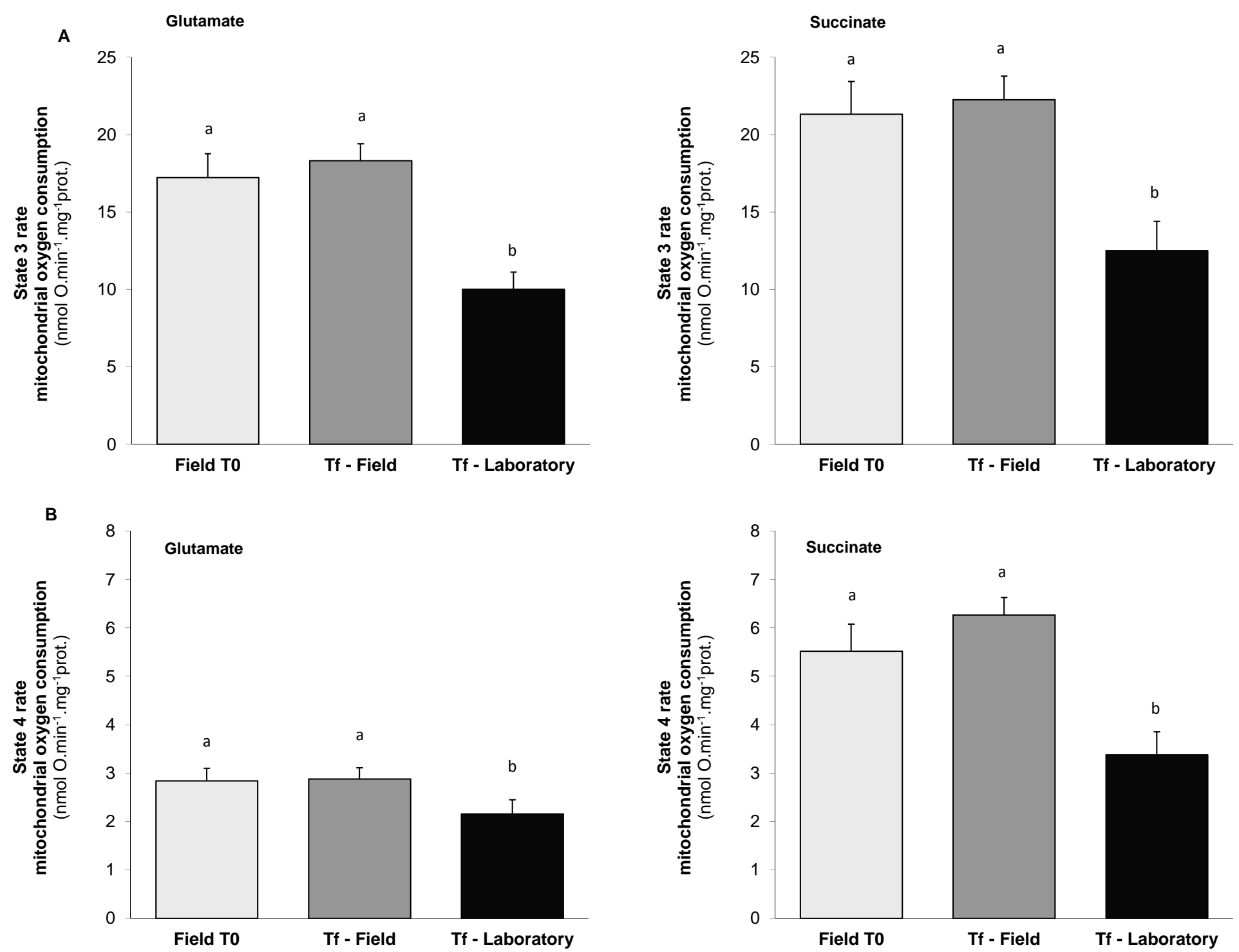

Figure 2 : Rates of oxidative phosphorylation (state 3) (A) and non-phosphorylating oxygen consumption (state 4) (B) with glutamate $40 \mathrm{mM}$ or succinate $20 \mathrm{mM}$ on mitochondria isolated from oysters grown in their natural environment or in the laboratory, and sampled before (Field TO) and after 4 weeks of conditioning (Tf Ç Field, Tf Ç Laboratory). Assay temperature was $10^{\circ} \mathrm{C}$. Different superscript letters indicate values that differ significantly $(p<0.05)$ between oyster groups (mean $\pm S E, n=6$ pools of 5 oysters). 
Table 1: Fatty acid composition of gill mitochondria phospholipids of oysters grown in their natural environment or in the laboratory, and sampled before (Field T0) and after 4 weeks of conditioning ( $\mathrm{Tf}-$ Field, $\mathrm{Tf}$ - Laboratory). The results are expressed as mol percentages of total fatty acids. Different superscript letters indicate values that differ significantly $(p<0.05)$ between oyster groups (mean $\pm \mathrm{SE}, \mathrm{n}=6$ pools of 5 oysters).

\begin{tabular}{|c|c|c|c|c|c|c|c|c|}
\hline & \multicolumn{2}{|c|}{ Field T0 } & \multicolumn{3}{|c|}{ Tf - Field } & \multicolumn{3}{|c|}{ Tf - Laboratory } \\
\hline & Mean & SE & Mean & & SE & Mean & & SE \\
\hline $14: 0$ & $1.4^{\mathrm{a}}$ & 0.0 & 1.5 & $\mathrm{a}$ & 0.1 & 1.8 & $\mathrm{~b}$ & 0.1 \\
\hline $16: 0$ & $10.3^{\mathrm{a}}$ & 0.1 & 12.2 & b & 0.4 & 11.1 & $\mathrm{c}$ & 0.1 \\
\hline 18:0 & $5.7^{\mathrm{a}}$ & 0.1 & 9.5 & b & 0.6 & 5.5 & c & 0.0 \\
\hline $16: 1 n-7$ & 2.2 & 0.1 & 1.9 & & 0.1 & 2.1 & & 0.1 \\
\hline 18:1n-9 & $1.3^{\mathrm{a}}$ & 0.0 & 1.6 & $\mathrm{~b}$ & 0.1 & 2.0 & $\mathrm{~b}$ & 0.1 \\
\hline $18: 1 n-7$ & $4.2^{\mathrm{a}}$ & 0.1 & 3.4 & b & 0.1 & 5.6 & c & 0.1 \\
\hline $20: 1 n-11$ & $1.5^{\mathrm{a}}$ & 0.0 & 2.1 & b & 0.0 & 2.6 & $\mathrm{c}$ & 0.1 \\
\hline $20: 1 n-9$ & $1.7^{\mathrm{a}}$ & 0.0 & 1.4 & $\mathrm{~b}$ & 0.0 & 1.4 & $\mathrm{~b}$ & 0.1 \\
\hline $20: 1 n-7$ & $5.4^{\mathrm{a}}$ & 0.0 & 4.7 & $\mathrm{~b}$ & 0.1 & 5.0 & $\mathrm{~b}$ & 0.0 \\
\hline $18: 2 n-6$ & $0.6^{\mathrm{a}}$ & 0.0 & 0.8 & b & 0.0 & 1.2 & $\mathrm{c}$ & 0.1 \\
\hline $18: 4 n-3$ & $1.3^{\mathrm{a}}$ & 0.1 & 2.1 & b & 0.3 & 1.0 & $\mathrm{c}$ & 0.0 \\
\hline $20: 4 n-6$ & $5.6^{\mathrm{a}}$ & 0.1 & 4.6 & $\mathrm{~b}$ & 0.1 & 4.4 & $\mathrm{~b}$ & 0.1 \\
\hline $20: 5 n-3$ & $19.4^{\mathrm{a}}$ & 0.2 & 16.4 & $\mathrm{~b}$ & 0.3 & 14.9 & c & 0.5 \\
\hline 22:2NMI $(7,13)$ & 1.9 & 0.1 & 1.9 & & 0.1 & 2.2 & & 0.1 \\
\hline $22: 2 \operatorname{NMI}(7,15)$ & $5.9^{\mathrm{a}}$ & 0.2 & 5.5 & $\mathrm{~b}$ & 0.1 & 7.4 & $\mathrm{c}$ & 0.1 \\
\hline $22: 3 \operatorname{NMI}(7,13,16)$ & $1.2^{\mathrm{a}}$ & 0.0 & 1.0 & $\mathrm{~b}$ & 0.1 & 0.9 & $\mathrm{~b}$ & 0.0 \\
\hline $22: 4 n-6$ & $0.6^{\mathrm{a}}$ & 0.0 & 0.5 & $\mathrm{~b}$ & 0.0 & 0.5 & $\mathrm{~b}$ & 0.0 \\
\hline $22: 5 n-6$ & $0.4^{\mathrm{a}}$ & 0.0 & 0.4 & a & 0.0 & 2.1 & $\mathrm{~b}$ & 0.2 \\
\hline $22: 5 n-3$ & $1.7^{\mathrm{a}}$ & 0.0 & 1.7 & $\mathrm{a}$ & 0.0 & 1.0 & $\mathrm{~b}$ & 0.0 \\
\hline $22: 6 n-3$ & $20.9^{\mathrm{a}}$ & 0.3 & 18.7 & $\mathrm{~b}$ & 0.6 & 20.1 & $\mathrm{ab}$ & 0.3 \\
\hline Others* & $3.8^{\mathrm{a}}$ & 0.1 & 4.9 & b & 0.2 & 3.7 & a & 0.1 \\
\hline Total BR & $0.5^{\mathrm{a}}$ & 0.0 & 0.5 & $\mathrm{a}$ & 0.0 & 0.3 & $\mathrm{~b}$ & 0.0 \\
\hline Total SFA & $17.6^{\mathrm{a}}$ & 0.2 & 23.4 & $\mathrm{~b}$ & 1.0 & 18.5 & $\mathrm{c}$ & 0.2 \\
\hline Total MUFA & $16.5^{\mathrm{a}}$ & 0.1 & 15.4 & $\mathrm{~b}$ & 0.3 & 19.1 & $\mathrm{c}$ & 0.1 \\
\hline Total n-9 & $3.2^{\mathrm{a}}$ & 0.1 & 3.1 & a & 0.2 & 3.7 & $\mathrm{~b}$ & 0.2 \\
\hline Total n-7 & $11.7^{\mathrm{a}}$ & 0.1 & 10.0 & $\mathrm{~b}$ & 0.2 & 12.7 & c & 0.1 \\
\hline Total PUFA & $65.4^{\mathrm{a}}$ & 0.3 & 60.6 & b & 0.8 & 62.1 & $\mathrm{~b}$ & 0.3 \\
\hline Total n-4 & $0.3^{\mathrm{a}}$ & 0.0 & 0.3 & a & 0.0 & 0.2 & $\mathrm{~b}$ & 0.0 \\
\hline Total n-6 & $8.4^{\mathrm{a}}$ & 0.1 & 7.7 & $\mathrm{~b}$ & 0.2 & 9.5 & $\mathrm{c}$ & 0.3 \\
\hline Total n-3 & $47.3^{\mathrm{a}}$ & 0.3 & 43.7 & $\mathrm{~b}$ & 0.7 & 41.1 & $\mathrm{c}$ & 0.5 \\
\hline Total NMI & $9.4^{\mathrm{a}}$ & 0.2 & 9.0 & $\mathrm{a}$ & 0.1 & 11.2 & $\mathrm{~b}$ & 0.2 \\
\hline
\end{tabular}

* Others : total of 21 fatty acids detectable (iso17:0, ant17:0, 20:0, 22:0, 24:0, 18:1n-11, 22:1n-9, $16: 2 \mathrm{n}-7,16: 2 \mathrm{n}-4,16: 3 \mathrm{n}-6,16: 4 \mathrm{n}-3,18: 2 \mathrm{n}-4,18: 3 \mathrm{n}-6,18: 3 \mathrm{n}-3,20: 2 \mathrm{NMI}(5,11), 20: 2 \mathrm{NMI}(5,13), 18: 5 \mathrm{n}-$ $3,20: 2 n-6,20: 3 n-6,20: 4 n-3,21: 5 n-3)$, none of which were more than $1 \%$.

BR: branched FA; SFA: saturated FA; MUFA: monounsaturated FA; PUFA: polyunsaturated FA;

NMI: non-methylene-interrupted FA 
Table 2: Content of total phospholipids and proportion of phospholipid classes in gill mitochondria of oysters grown in their natural environment or in the laboratory, and sampled before (Field T0) and after 4 weeks of conditioning ( $\mathrm{Tf}$ - Field, $\mathrm{Tf}$ - Laboratory). The results are expressed as mol percentages of total fatty acids. Different superscript letters indicate values that differ significantly $(\mathrm{p}<0.05)$ between oyster groups (mean $\pm \mathrm{SE}, \mathrm{n}=6$ pools of 5 oysters).

\begin{tabular}{|c|c|c|c|c|c|c|c|c|c|}
\hline & \multicolumn{3}{|c|}{ Field T0 } & \multicolumn{3}{|c|}{ Tf - Field } & \multicolumn{3}{|c|}{ Tf - Laboratory } \\
\hline & Mean & & SE & Mean & & SE & Mean & & SE \\
\hline $\mathrm{PE}$ & 29.8 & & 0.3 & 30.3 & & 0.2 & 30.6 & & 0.3 \\
\hline $\mathrm{PI}+\mathrm{CAEP}$ & 19.3 & $\mathrm{a}$ & 0.2 & 20.1 & b & 0.2 & 21.9 & c & 0.4 \\
\hline CL & 6.8 & $\mathrm{a}$ & 0.3 & 6.4 & $\mathrm{a}$ & 0.2 & 5.0 & b & 0.2 \\
\hline $\mathrm{PC}$ & 37.0 & $\mathrm{a}$ & 0.5 & 35.2 & $\mathrm{ab}$ & 0.6 & 33.4 & b & 0.9 \\
\hline PS & 7.1 & & 0.3 & 8.0 & & 0.7 & 9.0 & & 1.0 \\
\hline $\mathrm{PC} / \mathrm{PE}$ & 1.24 & a & 0.02 & 1.16 & $\mathrm{~b}$ & 0.03 & 1.09 & c & 0.02 \\
\hline $\mathrm{PE} / \mathrm{CL}$ & 4.4 & $\mathrm{a}$ & 0.2 & 4.8 & $\mathrm{a}$ & 0.2 & 6.1 & $\mathrm{~b}$ & 0.2 \\
\hline $\begin{array}{l}\text { Total phospholipid content } \\
\text { ( } \mu \text { g. } \mathrm{mg}^{-1} \text { prot.) }\end{array}$ & 471.3 & & 39.2 & 450.4 & & 7.9 & 394.7 & & 32.5 \\
\hline
\end{tabular}

PE : phosphatidylethanolamine; PI : phosphatidylinositol; CL : cardiolipin; CAEP : ceramide aminoethylphosphonate; PC : phosphatidylcholine; PS : phosphatidylserine 
Table 3: Respiratory control ratio (RCR) and oxidative phosphorylation efficiency (ADP/O), with glutamate $40 \mathrm{mM}$ or succinate $20 \mathrm{mM}$ as substrate and ADP $0.6 \mathrm{mM}$ of oysters grown in their natural environment or in the laboratory, and sampled before (Field T0) and after 4 weeks of conditioning ( $\mathrm{Tf}-$ Field, $\mathrm{Tf}$ - Laboratory). Different superscript letters indicate values that differ significantly $(\mathrm{p}<0.05)$ between oyster groups (mean $\pm \mathrm{SE}, \mathrm{n}=6$ pools of 5 oysters).

\begin{tabular}{|c|c|c|c|c|c|c|c|c|c|}
\hline & \multicolumn{3}{|c|}{ Field T0 } & \multicolumn{3}{|c|}{ Tf - Field } & \multicolumn{3}{|c|}{ Tf - Laboratory } \\
\hline & Mean & & SE & Mean & & SE & Mean & & SE \\
\hline RCR glutamate & 6.2 & $\mathrm{a}$ & 0.5 & 6.4 & a & 0.2 & 4.8 & $\mathrm{~b}$ & 0.4 \\
\hline RCR succinate & 3.9 & $\mathrm{a}$ & 0.1 & 3.6 & b & 0.1 & 3.3 & $\mathrm{~b}$ & 0.2 \\
\hline $\mathrm{ADP} / \mathrm{O}$ glutamate & 2.6 & $\mathrm{a}$ & 0.2 & 2.0 & $\mathrm{~b}$ & 0.0 & 2.3 & $\mathrm{ab}$ & 0.3 \\
\hline $\mathrm{ADP} / \mathrm{O}$ succinate & 1.9 & $\mathrm{a}$ & 0.1 & 1.6 & b & 0.1 & 1.8 & $\mathrm{ab}$ & 0.2 \\
\hline
\end{tabular}


Table 4: $\mathrm{CCO}$ activity, expressed per $\mathrm{mg}$ of mitochondrial proteins or per $\mathrm{nmol}$ of cytochrome $a$, and CS activity, expressed in per $\mathrm{mg}$ of gill tissue of oysters grown in their natural environment or in the laboratory, and sampled before (Field T0) and after 4 weeks of conditioning ( $\mathrm{Tf}$ - Field, $\mathrm{Tf}$ - Laboratory). Assay temperature was $25^{\circ} \mathrm{C}$. Different superscript letters indicate values that differ significantly $(\mathrm{p}<0.05)$ between oyster groups (mean $\pm \mathrm{SE}, \mathrm{n}$ $=6$ pools of 5 oysters).

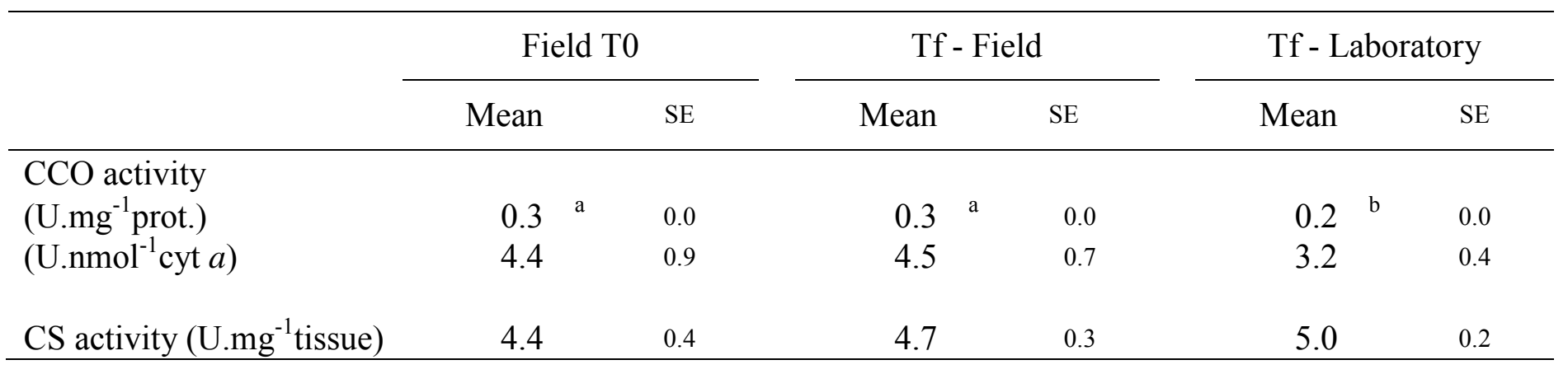


Table 5: Concentrations of mitochondrial cytochromes $a, b, c_{1}$ and $c$, expressed as nmol of cytochrome per mg of mitochondrial proteins, relative cytochrome ratios related to cytochrome $c_{1}$ and ratio $\left(b+c_{1}\right) / a$ of oysters grown in their natural environment or in the laboratory, and sampled before (Field T0) and after 4 weeks of conditioning ( $\mathrm{Tf}$ - Field, Tf - Laboratory).

Different superscript letters indicate values that differ significantly $(\mathrm{p}<0.05)$ between oyster groups ( $m e a n \pm \mathrm{SE}, \mathrm{n}=6 \mathrm{pools}$ of 5 oysters).

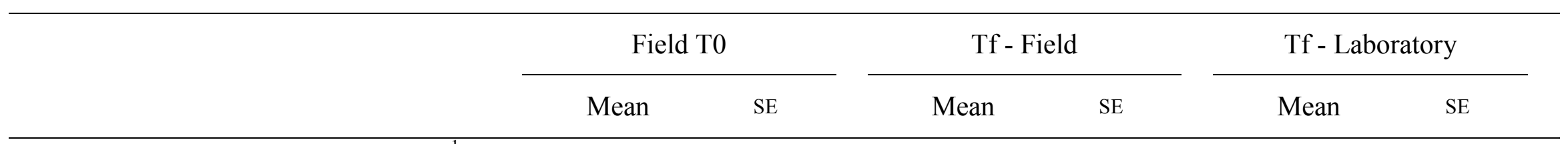

Cytochrome concentrations (nmol.mg ${ }^{-1}$ prot.)

a

$b$

$c_{1}$

c

Total

Relative ratios

$a / c_{1}$

$b / c_{1}$

$c / c_{1}$

$\left(b+c_{1}\right) / a$

7

8

$\begin{array}{lllllll}0.07 & & 0.01 & 0.06 & 0.01 & 0.05 & 0.01 \\ 0.21 & \text { a } & 0.02 & 0.21 & \text { a } & 0.02 & 0.16 \\ 0.12 & 0.01 & 0.13 & 0.01 & 0.12 & 0.01 \\ 0.06 & 0.01 & 0.08 & 0.01 & 0.06 & 0.01 \\ 0.45 & 0.03 & 0.48 & 0.04 & 0.38 & 0.03\end{array}$

